\title{
ASPECTS OF TAXATION OF SO-CALLED PROFIT TAX ESTONIAN MODEL AND ITS IMPACT ON BUSINESS ENVIRONMENT OF GEORGIA
}

Paata Shurgaia,

Associate Professor,

Georgian National University SEU

\begin{abstract}
Existence of investment policy and investments in general play an important role in boosting the country's economy and maintaining the growth trends of macroeconomic factors. The Georgian economy at the policy level determines the need to achieve a large scale of both foreign direct investment and domestic investment. Consequently, the opportunities of the Georgian economy are directly related to the volume of investments, and the volume of investments is conditioned by the existence of an effective and efficient investment climate in the country. Which institutional factor holds the greatest weight in the investment environment? - Tax policy is one of the most important issues among institutional factors. For the reason of economic stimulation and development, Georgian government adopted changes in relation to entrepreneurship activates. Various researches and prognosis were made regarding implementation of so called "Estonian Model" of profit tax by Governmental, Business and Academic bodies. Pre and post reform period arose many questions and the answers are still vague. What contribution was made by the reform for encouragement of the Foreign Direct Investments? How has the labor productivity been increased? How has the reform simplified access to the capital resources? In this research paper the author discusses the Profit tax "Estonian Model" prognosis and expectations as well as analysis of the actual results in Georgia and Estonia. The Author conducts qualitative and critical research methodologies. On the basis of demonstration of the actual circumstances, the reform has been assessed in short and long term perspective.
\end{abstract}

Keywords: Profit Tax Estonian Model; Corporate Taxation; Tax Burden \& FDI; Tax Policy.

\section{Introduction}

In the context of economic expansion, where in the wake of the development of technology and capital markets, it has become critical to diversify the sources of income of individuals (including sole proprietors) and legal entities, both strategically and emerging countries, as well as by type of economic activity. Consequently, great importance is attached to the tax policies of the country, including the aspects of international taxation of transactions. The activities of transnational and international companies in different geographical areas lead to different tax conditions of companies, which affects the financial performance of the company in the reporting periods, and globally, similar results affect the placement of foreign direct investment or local investment growth. Having said this, tax law plays a fundamental role in creating a stimulating legal environment for businesses. To achieve this, tax law must offer entrepreneurs favorable, predictable and fair terms. It should be noted that since gaining independence, Georgia has been able to implement significant reforms to develop the fiscal efficiency of the economy. Consequently, one of the most successful reforms can be considered the country's tax policy orientation. 


\section{Profile of Georgian Tax System}

Daily changes in the economic environment have added to the importance of tax policy in the various decisionmaking processes of firms. The economic policy of the government can be achieved mainly through tax policy. The so-called Tax incentives are a tool for effective growth of domestic investment and foreign direct investment. Tax incentives imposed by countries should be carefully planned so that fiscal incentives do not lead to the existence of tax loopholes, while firms can benefit from tax evasion and avoidance. The reforms (evolution) implemented in tax law during the independence of Georgia can be divided into three main parts. The modern tax system in Georgia was first established in 1997, which took into account important aspects of international experience and the findings of developing countries.

As for the wave of reforms, for the First Time such significant changes and reforms were implemented after the Rose Revolution in 2005, which fundamentally transformed the economic scale of the country and led to an increase in foreign direct investment. Moreover, according to the Tax Reform and Poverty Index, which was conducted by Forbes magazine, Georgia has made significant progress and has taken a leading position. ${ }^{1}$ With the reforms implemented, the country has become a leading jurisdiction in the region with its liberal economic policies and significant reduction of the tax burden. The so called second wave of the reform can be considered the year 2011, where the relationship with the state structure (Revenue Service) was significantly simplified. These changes have eased the time required for bureaucratic and administrative processes and significantly digitized tax processes. An electronic website (rs.ge) has been set up by the Revenue Service, an agency within the Ministry of Finance, which allows taxpayers to independently manage processes electronically. Processes include communication with the Revenue Service, production and submission of declarations, management of primary documents - submission, receipt, etc. As for the Third Wave, it is directly related to the step taken to stimulate foreign direct investment. In order to increase and accelerate the economic prosperity, in 2016 the so-called Estonian Model of Profit Tax system was introduced. The tax regime came into force in the reporting period of 2017. Over the years, the Tax Code has undergone various changes related to the fulfillment of its obligations under the Association Agreement with the European Union. ${ }^{2}$

According to a joint study by audit and business consulting firm $\mathrm{PwC}$ and the World Bank, Georgia ranked 14th out of 190 countries in terms of Paying Taxes in 2020. ${ }^{3}$ Tax simplicity is assessed according to three criteria, namely:

1) The number of taxes the company has to pay

2) The number of hours the company spends on average in paying taxes during the year

3) Total tax rate, which shows the share of commercial profit in total taxes paid by the company ${ }^{4}$

As for the Index score in 2016, Georgia ranked 40th in terms of ease of payment.

Figure 1 - Paying Taxes 2016

\footnotetext{
${ }^{1}$ Forbes Magazine, „2009 Tax Misery and Reform Index”, https://www.forbes.com/global/2009/0413/034-tax-misery-reformindex.html? sh=1004e65e43b3, [L.s. 11.04.2021].

${ }^{2}$ N. Gilauri, „Practical Economics”, „Palgrave Macmillan”, 2017, pg. 31-40.

${ }^{3}$ World Bank Group and PwC, „Paying Taxes 2020”, https://www.doingbusiness.org/en/reports/thematic-reports/paying-taxes-2020, [L.s. 12.04.2021].

${ }^{4}$ World Bank Group and PwC, ,Paying Taxes 2016”,https://www.pwc.com/gx/en/paying-taxes-2016/paying-taxes-2016.pdf, [L.s. 12.04.2021].
} 


\section{Overall}

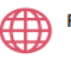

Rank (out of 189)

The Paying Taxes score

Total Tax \& Contribution rate 16.4

(D) Time to comply 269

Number of payments 5.0

Post-filing index

-

According to the mentioned research in 2020, the author made a comparison according to the number and rates of taxes in Georgia and its neighboring countries. Number of taxes and total tax rates.

Figure 2 - Corporate Tax Rate vs. Number of Taxes

60

50

40

30

20

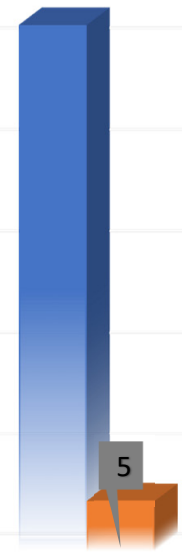

Ukraine
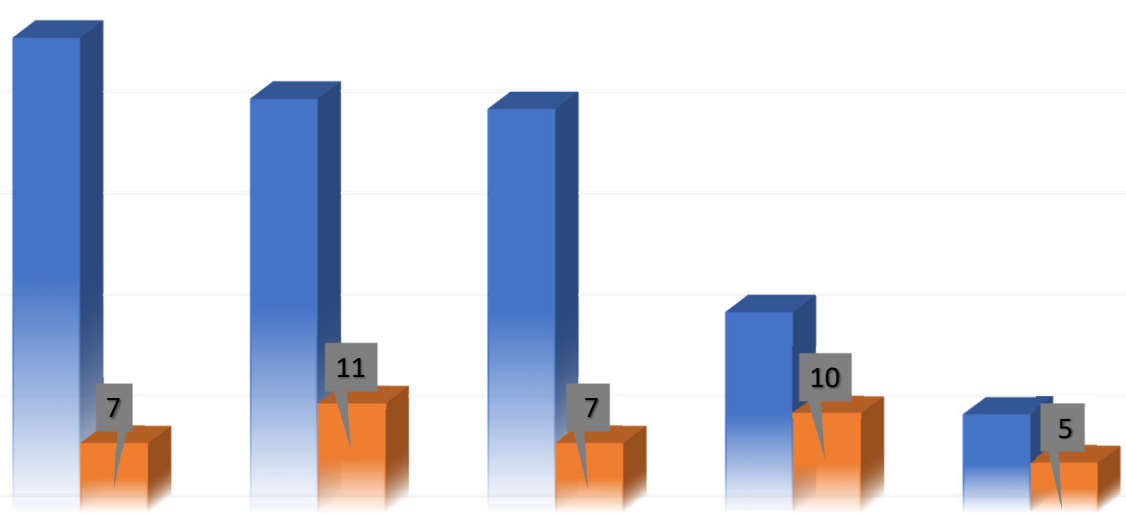

Russia

Turkey

Azerbaijan

Armenia

Georgia

- Total Corporate Tax Rate (\%) $=$ Number of Taxes

The tax rates have been significantly reduced in the wake of substantive and administrative changes. The tax classification in force today looks like this: 


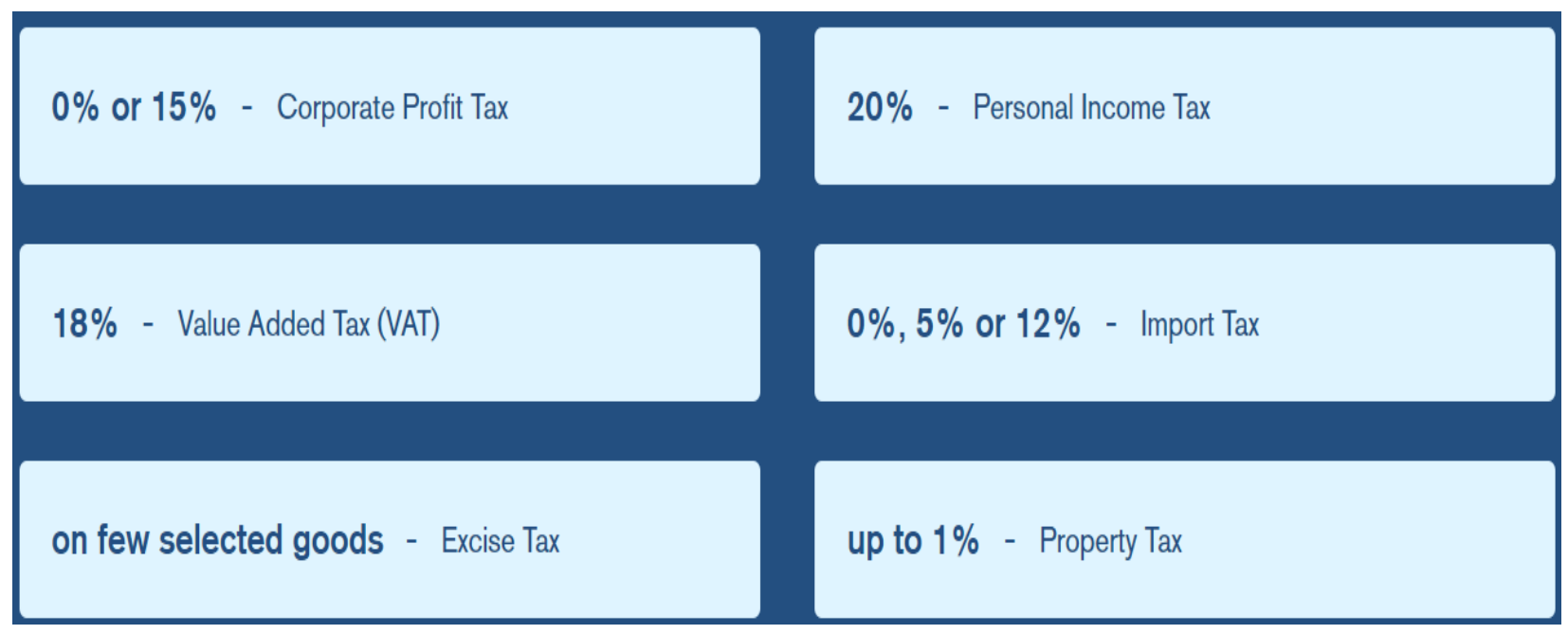

According to the World Bank 2020 research of Doing Business, Georgia dropped one point in the ranking and took the 7th place among 190 countries with 83.7 points. Although the country had a 0.2 point improvement, it did not turn out to be enough to advance in the country rankings. The study (rating) has been conducted by the World Bank since 2003 and up to 190 countries participate in the study. The Ease of Doing Business Index measures 10 items in your quotes. In particular, these are: 1) starting a business; 2) construction permit; 3 ) Email. Supply; 4) property registration; 5) receiving a loan; 6) protection of the rights of minority investors; 7) payment of taxes; 8) trade between borders; 9) execution of the contract; 10) Insolvency. ${ }^{5}$

The Doing Business Index is one of the most valuable and defining tools for making investment decisions, so the Georgian government has implemented significant reforms since 2005 to improve its ranking. Georgia is ahead of countries such as Great Britain, Norway, Estonia, Germany, etc. However, it lags behind the US, Denmark, Singapore, and New Zealand. Country assessments in recent years look like this.

The goal of the Georgian government is to maintain and improve its position in the ranking of doing business. The reason for this is the attractiveness of the Georgian business environment from investors and, in general, it is profitable to be at the forefront of such assessments and studies. In recent years, we can highlight several important reforms that have been carried out by the government of the country and also, have significantly contributed to the positive assessments of the country and the promotion of the elements described above. From the reforms we can single out:

1. Profit tax reform. Introduction of the so-called Estonian model;

2. Removal of the mandatory component of value added tax as a result of mergers;

3. Opportunity to start a business, namely registration, opening bank accounts, creating a tax administration portal, etc. All this can be done in one working day.

However, there are some important elements that need and require significant improvement. In particular, the judiciary and the protection of business rights; Increase access to and access to credit; Execution of contracts; Insolvency proceedings, etc. The assessment of Georgia's positions in each of the elements looks like this:

\footnotetext{
${ }^{5}$ See footnote 3 .
} 
Figure 4 - Assessment of Elements based on DB 2020
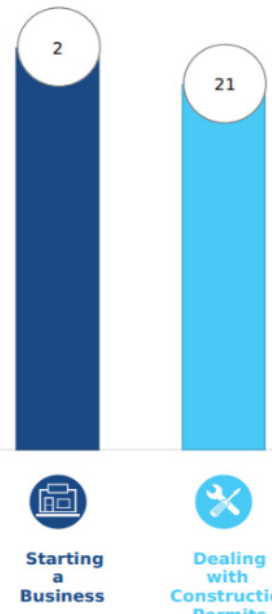
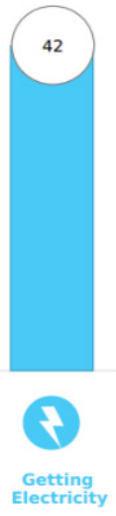
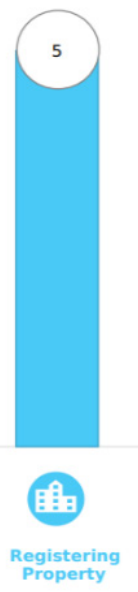
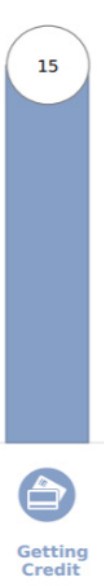
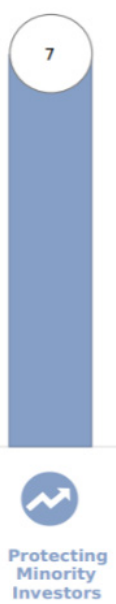
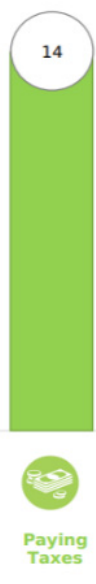
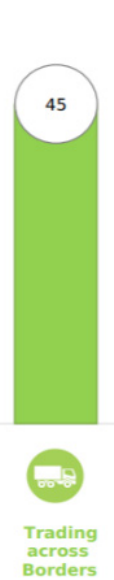
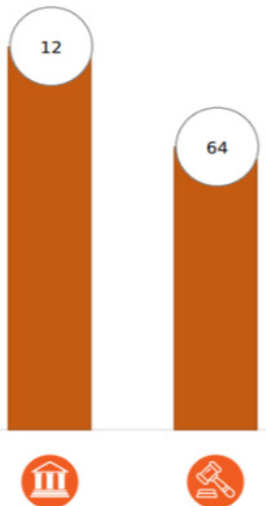

Enforcing
Contracts

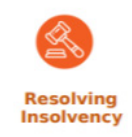

Following in the footsteps of the reforms carried out, Georgia has become a leader in the region and, according to a study by many international organizations to the following year indexes, one of the leading countries in the world ranking in terms of ease of starting a business. ${ }^{6}$

The presence of leading positions in those elements are conducive to the country's economic development and attracting foreign direct investment. However, it should be noted that even being in the first position in the rankings is not enough for a country like Georgia, because we have to look for problems in other elements, which are not evaluated in the study of doing business. Such elements are a deep and fundamental problem of the country and include issues such as education, political instability, territorial location and the existence of conflicts, judiciary, lack of confidence and lack of sense of business protection, including protection of private property, unprofessional workforce.

\section{Tax Purposes and Essential of Profit Tax}

The country's tax policy has important goals and objectives. And the existence of taxes is an important tool for policy-making. In general, the purposes and effects of taxes are based on the so-called $4 \mathrm{R}$ function.

The first $\mathrm{R}$ represents the means of generating income. Revenue function through which the state functions and fulfills its obligations. The second $\mathrm{R}$ is a distribution function. Redistribution function, where the role of the state is primarily manifested in vulnerability. The next $\mathrm{R}$ implies influencing the production / purchase of state-defined services and goods. Basically this is done by value adjustment and is called the Repricing function, e. g. Import tax on goods, taxation of fuel excise, etc. The fourth R has only a historical load, because in the modern era there is no country tax system with a Representative function. This implies the participation of taxpayers in the management or representation of the country. ${ }^{7}$

Taxation is classified according to its content and nature, in particular:

a. According to the content, direct and indirect (indirect) taxes;

\footnotetext{
${ }^{6}$ PwC, „Doing Business and Investing in Georgia” 2019, https://www.pwc.com/ge/en/assets/pdf/Doingbusiness_2019_Final.pdf [L.s.12.04.2021].

${ }^{7}$ OECD, „Fundamental principles of taxation”, 2014, chapter 2, pg. 30-49.
} 
b. Progressive, regressive, proportional and fixed type taxes according to the change of rates;

c. General-state and local (also referred to as optional) taxes;

d. Target and general / universal taxes according to the purpose;

e. Out of regularity can be systematic and one-time taxes.

Profit tax, according to its content, is a direct type, systematic tax based on proportional basis, which belongs to the general state type taxes. Profit tax plays an important role in shaping the country's budget. ${ }^{8}$

\section{Assessment of Profit Tax Estonian Model}

As mentioned above, the Georgian government took an important step in 2017 by changing the tax payment period and the principle of taxation in the third wave. The so-called The Estonian model of profit tax implies the shift of the profit tax period from its generation to distribution. In particular, the so-called classic model. Instead of the accrual principle, switch to the cash principle, which implies the payment of profit tax only in the case of its distribution. The main pathos of the reform was to encourage foreign direct investment and domestic industrial investment in the country and to promote the growth of macroeconomic factors. At some point in time, this decision should provide incentives for investment decisions, especially: ${ }^{9}$

1. Increase of economic / macroeconomic parameters;

2. Increase / expansion of capital scale;

3. FDI - acceleration of foreign direct investment;

4. Improving the (investment) environment needed to start a business;

5. Minimize risks related to crisis factors from the business side.

The so-called distributed profit the Estonian model has been in force in the country where it will be implemented for the first time for more than 16 years, and the basic principles of corporate taxation in Estonia are fully in line with the example of Georgia. The perspective and inspiration for its implementation and economic development in Georgia came from here. The essence of corporate tax in Estonia implies the moment of taxation only in case of its distribution, in particular, both cash and non-cash, including the distribution of dividends in tangible and intangible forms, redemption of capital or shares, including reduction of capital, distribution of capital assets in the liquidation process if it does not exceed first contributions by partners. ${ }^{10}$ The principles of corporate taxation are based on the distribution of the wealth created by the enterprise to its final beneficiaries, in monetary - tangible or intangible form, so any type of transaction that meets the above principle is a profit distribution and is a taxable transaction, including direct or indirect transactions. ${ }^{11}$ While it is not clear what direct distribution models are, non-directive pathways need to be considered. The tax authorities in order to close the bypass distribution, in order to legalize illegal income or to minimize and avoid money laundering risks, the Tax Code, which allows tax evasion through holes, the legislation provides for a detailed list of transactions. In particular, operations such as: ${ }^{12}$

\footnotetext{
${ }^{8}$ Government of Georgia, „Budget Monitory”, 2016.

${ }^{9}$ Ministry of Finance, ,Fiscal Policy and EU practice”, 2016.

${ }^{10}$ J. Masso \& Others, „Gross Profit Taxation Versus Distributed Profit Taxation and Firm Performance: Effects of Estonia's Corporate Income Tax Reform”, ,JOUR” 2011, pg. 49-55.

${ }^{11}$ M. Leibrecht \& Others, „Do low corporate income tax rates attract FDI? - Evidence from Central- and East European countries”, „Applied Economics" 41, 2009, pg. 2691-2703.

${ }^{12}$ Clause 97, Law of Georgia „, Georgia Tax Code” 12, October, 2010.
} 
$>$ Transactions related to offshore countries, where the performed operations are not controlled for the purposes of the Tax Code of Georgia;

$>$ Representation expenses that exceed the marginal amount. Marginal amount - not more than 1 percent is related to the income and expenses incurred by the enterprise, where the Georgian tax code determines which element one percent should be taken;

$>$ Provision of services and / or goods, including transfer of funds, free of charge (without compensation);

$>$ Finally, any type of transactions that are not related to or associated with the economic activities of the enterprise, as well as transactions that cannot be substantiated by primary documents.

As in Georgia, the new corporate tax regime introduced in Estonia has led to a reduction in budget revenues for the country. According to the official data of the Statistics Service, the revenues in the year of implementation of the reform were almost halved compared to the data of the previous year. The reform not only had an impact on revenues, but also a significant reduction in GDP. ${ }^{13}$ In terms of numbers, corporate revenue fell from 1,600 million to 900 million, while relative to GDP, it fell from 2 percent to 0.92 percent. However, the recovery of economic factors began in the years following the introduction of the reform, while not all of these periods saw a decline in foreign direct investment ${ }^{14}$.

Figure 5 - Corporate Income Tax Revenue, Estonia, 1994 - 2004

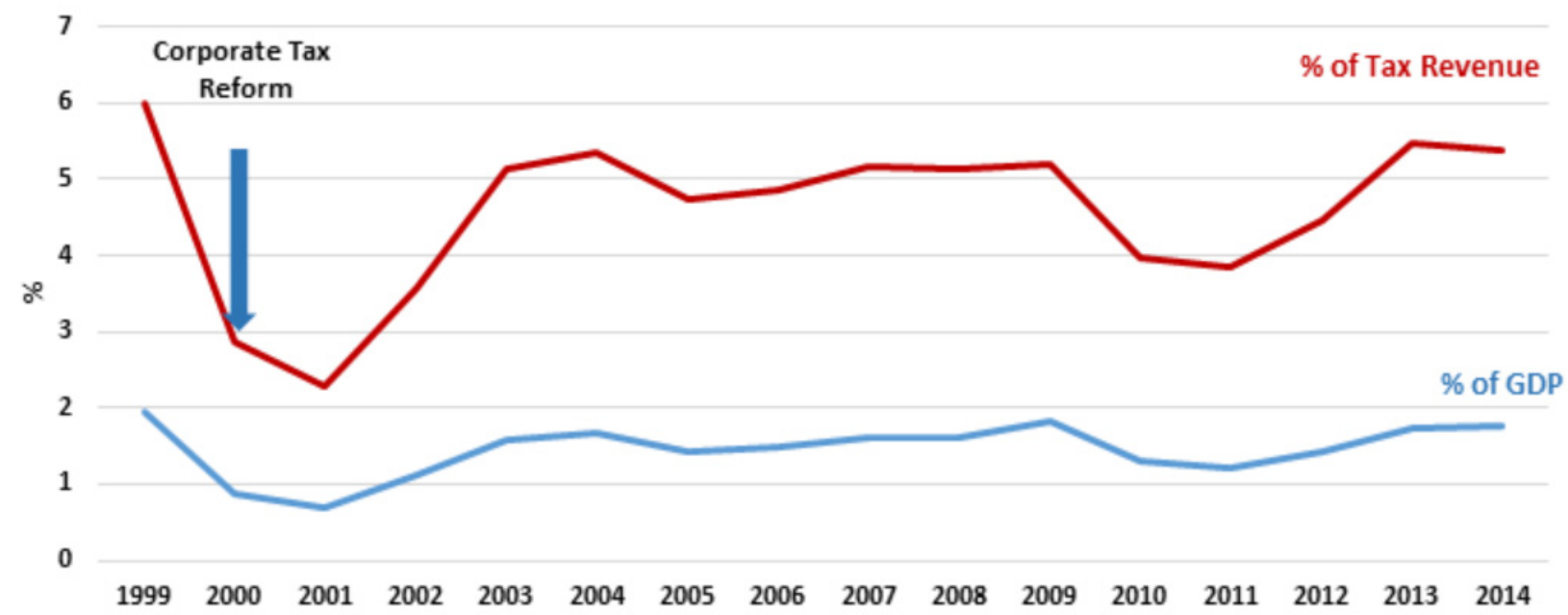

According to well-known researchers by Leibrecht Markus \& Bellak, Christian, in other things being equal, fiscal policy reform alone may not be a decisive factor, as factors such as market size, geographical location, labor market, geopolitical situation, etc. are driven by foreign direct investment and so ${ }^{15}{ }^{15}$. In addition, according to a study by Masso, Jaan and Meriküll Jaanika and Vahter, Priit, the reform implemented by the country significantly increased the scale of liquid assets and provided loans to finance the activities of

\footnotetext{
${ }^{13}$ Geostat, 2020.

${ }^{14}$ M.Kantsukov, and P. Sander. 2018. 147-156.

${ }^{15}$ See footnote 11 .
} 
companies. Moreover, the correlation rate between labor productivity and investment has increased. Taking into account the above factors and the results obtained, business sustainability has developed, which has given companies an additional opportunity to more or less cope with the global financial crisis of $2008 .{ }^{16}$

As for Georgia, the implementation of the profit tax reform should have significantly reduced the budget tax revenues, while corporate taxation played an important role in the formation of the budget, in particular, it was the third largest type of tax in the formation of the budget. The contribution of profit tax in terms of revenue was almost twelve percent of total treasury revenue and ten percent of treasury expenditure. All the forecasts (including those made by financial institutions) indicated that the abolition (deferral) of corporate tax would lead to a reduction in budget revenues in the short run, while in the long run it should have been a positive charge carrier. In response to declining revenues, the government has increased revenues from other taxes and reduced the crisis by responding to the problem of fiscal losses by raising excise rates, creating additional tax burdens on a number of businesses and services.

Figure 6 - Profit Tax \& Total Tax Revenue in Georgia

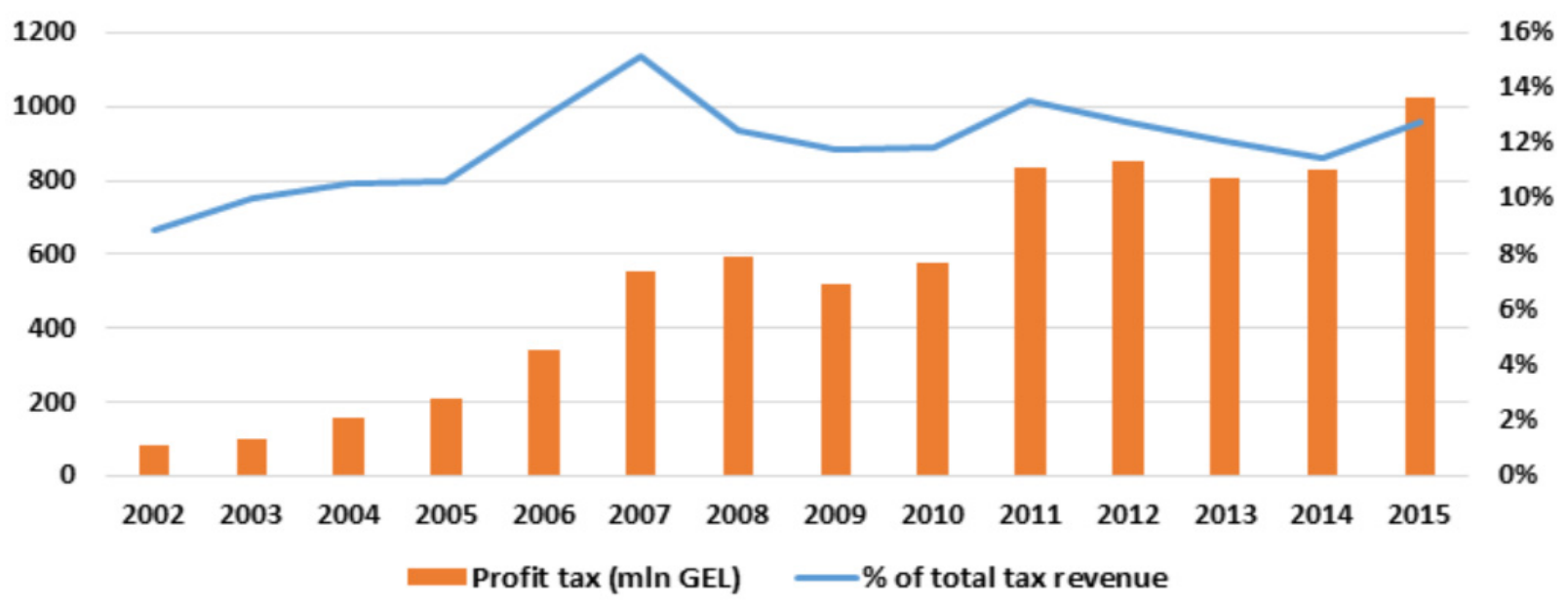

Figure 7 - FDI in Georgia 2011 - 2020

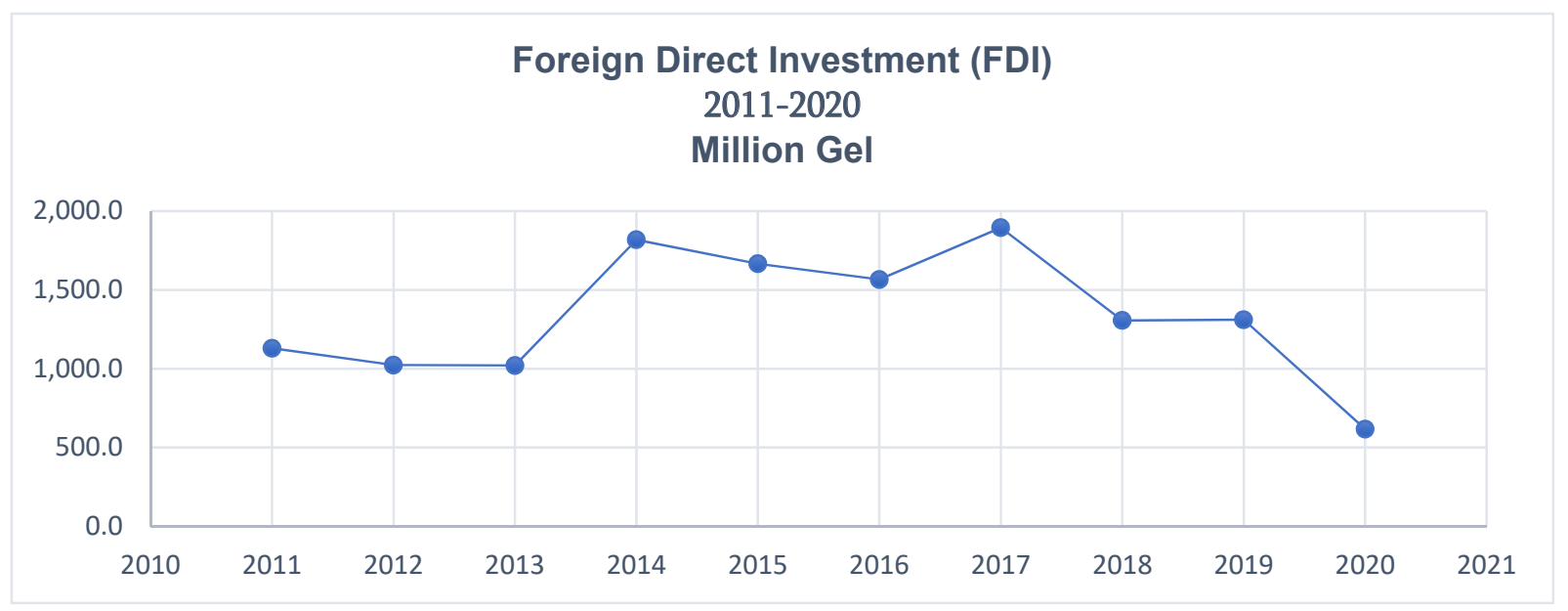

16 See footnote 10 . 
Profit tax held a stable share of the country's budget revenues, and its percentage, on average in recent years, was $11 \%$. Profit tax and budget income share by years looks as follow:

Figure 8 - Profit Tax vs. Budget share in \%

\begin{tabular}{|l|c|c|c|c|c|c|c|c|c|}
\hline \multicolumn{1}{|c|}{ Year } & 2013 & 2014 & 2015 & 2016 & 2017 & 2018 & 2019 & 2020 \\
\hline $\begin{array}{l}\text { Profit tax (million } \\
\text { GEL) }\end{array}$ & 807 & 829 & 1025 & 1055 & 756 & 736 & 866 & 919 \\
\hline
\end{tabular}

In other words, the content of the reform is based on the theory of economic growth and the studies that have been conducted between economic growth and the size of government, obviously the size of government, as a result of the reform is reduced to other equal conditions. According to the majority of studies conducted to determine the correlation between economic growth and government size, a reduction in the size of government, in other things being equal to GDP, is accelerating the rate of economic growth.

In the fall of 2015, USAID G4G project in Georgia the so-called corporate tax was implemented within the framework of funding for "Governance for Development". Estimating the implementation of the Estonian model with the RIA - Regulatory Impact Assessment Model. ${ }^{17}$ More precisely, a neo-classical model was used, on the basis of which economic effects were predicted. Against the background of individual reservations, the reform was to have a positive effect on both foreign direct investment and domestic investment decisions, to develop capital markets and, ultimately, to reflect gross domestic product. At the same time, pursuant to this report on the report done for USAID G4G project - the reform should have following results, namely:

$>$ The reform has an investment incentive effect. Stock capital will increase by $3.23 \%$ in 1.5 years. The reform will lead to an increase in net investment. Economic agents are investing more than ever before;

$>$ In about 1.5 years, real GDP will grow by $1.44 \%$;

$>$ Total private consumption will increase by about $0.85 \%$ in 1.5 years;

$>$ The reform will increase the annual government budget deficit by a maximum of $3 \%$. At the same time, an increase in income tax by $1 \%$ and an increase in value added tax by $1.25 \%$ will eliminate this deficit. In order to achieve a new budget balance, the government should consider not increasing spending within 2-3 years after the reform;

${ }^{17}$ PMC Research Centre, „Regulation Impact Assessment - Profit Distribution Model so called Estonian Model”, 2016, pg. 5-19. 
The current account deficit will be slightly reduced as companies leave dividends in Georgia due to the investment effect of the reform;

$>$ The result of the reform will become tangible in about 1.5 years.

The Gross Domestic Product development of Georgia in all items following the reform looks as follow:

Figure 9 - GDP Development Per Item

\begin{tabular}{|c|c|c|c|c|c|c|c|c|}
\hline & 2017 & 2018 & 2019 & $120^{*}$ & II $20^{*}$ & III $20^{*}$ & IV $20^{*}$ & $2020^{*}$ \\
\hline GDP at current prices, billion GEL & 40.8 & 44.6 & 49.3 & 11.1 & 11.1 & 13.3 & 13.9 & 49.4 \\
\hline $\begin{array}{l}\text { GDP at constant } 2015 \text { prices, } \\
\text { billion GEL }\end{array}$ & 36.6 & 38.4 & 40.3 & 9.1 & 8.8 & 9.8 & 10.2 & 37.8 \\
\hline $\begin{array}{l}\text { GDP real growth, percentage } \\
\text { change }\end{array}$ & 4.8 & 4.8 & 5.0 & 2.3 & -13.2 & -5.6 & -6.8 & -6.2 \\
\hline GDP deflator, percentage change & 8.5 & 4.4 & 5.2 & 7.1 & 7.2 & 5.9 & 7.4 & 6.9 \\
\hline GDP per capita (at current prices), & & 11 & 13 & & ר: & $0,50<7$ & 27410 & 7 \\
\hline $\begin{array}{l}\text { GDP per capita (at current prices), } \\
\text { USD }\end{array}$ & 4358.5 & 4722.0 & 4696.2 & 1016.3 & 952.9 & 1156.2 & 1144.1 & 4274.6 \\
\hline GDP at current prices, billion USD & 16.2 & 17.6 & 17.5 & 3.8 & 3.5 & 4.3 & 4.3 & 15.9 \\
\hline
\end{tabular}

The authors of the study also consider the level of protection of democracy and property rights important, as these factors are important in assessing forecasting risks, although it should be noted that the Georgian economy is more resilient than Estonia in carrying out such reforms, such as labor rights, monetary freedom, ease of doing business, etc. With these figures, Estonia was significantly behind Georgia's current readiness for reform before implementing the profit tax reform.

Despite many positive developments, the implementation of the reform was characterized by certain risk factors, which meant that the period before the reform differed significantly between Georgia and Estonia, in particular, the tax burden and scale of withdrawing money from business was much lower than in 2000 in Estonia. Apart from this moment, unlike Estonia, Georgia was more dependent on budget revenues, one of the most important sources of which was the profit tax. The move by the government to offset one tax with another, namely postponing or canceling the profit period, a direct proportional increase in the excise tax rate has slowed down the expected and anticipated effects of the reform. As a result, one step forward was shortened by the step back by the other foot. Furthermore, we can conclude that the government has undertaken a significant tax reform, which should have been followed by a budget reform to change the size of government to GDP, which in other equal conditions would accelerate economic growth, as the tax and budget sectors are part of a single, fiscal policy. 


\section{Conclusion}

As a summary, we can assess that the Georgian government has introduced a so-called profit tax. The implementation of the Estonian model has enabled the development of small and medium-sized businesses. As for the reform implemented in Estonia, the economic result obtained as a result of the reform there is remarkable, as the macroeconomic parameters have changed significantly in the long run. While the reform implemented in Georgia was related to many other factors and assumptions. The reform did not give the country an instant effect, even though it is still used as an image element for investors. However, reform in the medium and long term should determine the expectation of stable economic growth, here too it is fundamental to note economic growth in other equal conditions, as sudden shocks can fundamentally change supplydemand chains, which occurred in the Covid-19 era. It is very far from estimation and calculation. The steps taken by the country to increase the excise tax have been negatively assessed, while the reduction in revenue should have been offset by a reduction in administrative costs and a reduction in bureaucratic mechanisms. Which would have made government activities more flexible in some cases and interfering in the life of the community and business. At the same time, it is advisable that the expectations, assumptions and reservations are properly made and that stakeholders take all measures to maximize the results of the resources spent. Whereas the implementation of the reform is accompanied by both time and financial costs, and the right expectations have the opportunity to dispel the imagination, if there are no political signs in it. This is because expectations for reform for the government, business and society seem to have been exceeded. 


\section{Bibliography:}

1. EPRC. 2020. "Economic Policy Research Center." http://eprc.ge. May 1. Accessed 04 19, 2021. http://eprc.ge/index.php?m=11\&news_id=239.[Last seen11.04.2021];

2. Forbes Magazine, 2009. 2009. Forbes. March 11. Accessed 04.11.2021. https://www.forbes.com /global/2009/0413/034-tax-misery-reform-index.html?sh=568d2a8143b3 [Last seen 11.04.2021];

3. Formaini, Robert. "Theory of Free International Trade." Economic Insights: Federal Reserve Bank of Dallas 3-9, 2013;

4. Georgian Tax Code, 2018. 2018. www.matsne.gov.ge. March 23. Accessed 04 21, 2021. https://www.matsne.gov.ge/en/document/view/1043717?publication=152. [Last seen 11.04.2021];

5. Geostat.ge. 2020. geostat.ge. 12 9. Accessed 04 13, 2021. http://www.geostat.ge /?action=page\&p_id=2230\&lang=geo.

6. GeoStat.ge. 2020. http://www.geostat.ge. 12 09. Accessed 03 31, 2021. http://www.geostat.ge/?action=page\&p_id=2230\&lang=geo. [Last seen 11.04.2021];

7. Nika Gilauri, Practical Economics. London: Palgrave Macmillan. 2017;

8. Practical Economics: Economic Transformation and Government Reform in Georgia 2004-2012. London: Palgrave Macmillan. 2017;

9. Goverment of Georgia. 2016. Goverment of Georgia, Budget Monitory, 2016. Tbilisi: mof.ge.

10. Gregorio, Jose De, and Jong-Wha Lee. 1998. "How does foreign direct investment affect economic growth?" Journal of international Economics 45 (1): 115-135;

11. Mark Kantsukov, and Priit Sander. "A LESSON IN VALUATION FROM ESTONIA: THE DIFFERENCE BETWEEN THE FUNDAMENTAL VALUE OF EQUITY UNDER DISTRIBUTED AND TRADITIONAL PROFIT TAXATION SYSTEMS." BUSINESS: THEORY AND PRACTICE. 2018;

12. Markus Leibrecht, and Christian Bellak. "Do low corporate income tax rates attract FDI? Evidence from Central- and East European countries." Applied Economics, 41 2691-2703. 2009;

13. Livny, Eric, and Maya Grigolia. http://iset-pi.ge. 12 09. Accessed 03 25, 2021. http://isetpi.ge/index.php/ka/iset-economist-blog/entry/estonia-inspiring-georgian-reformers-1, 2016;

14. Giorgi. Maldzigashvili, Governing for Growth in Geogria, Governing for Development. Report, Tbilisi: USAID in Georgia. 2019;

15. Masso, Jaan, Jaanika Meriküll, and Priit Vahter. "Gross Profit Taxation Versus Distributed Profit Taxation and Firm Performance: Effects of Estonia's Corporate Income Tax Reform.", 2011;

16. Ministry of finance. Fiscal Policy and EU practice. Tbilisi: Ministry of Finance. 2016. https://mof.ge/images/File/public\%20finances\%20in\%20Geo/Fiscal\%20Governance\%20\%20stud y\%20GEO\%20saboloo.pdf. [Last seen 12.04.2021];

17. MoF. 2021. matsne.gov.ge - Georgia Tax Code. March 23. Accessed 03 25, 2021. https://www.matsne.gov.ge/en/document/view/1043717. [Last seen 11.04.2021];

18. OECD. 2014. Fundamental principles of taxation. Paris: OECD Publishing;

19. OECD. 2020. Tax and Fiscal Policy in Response to the Coronavirus Crisis: Strengthening Confidence and Resilience. Paris: OECD Publisher; 
20. PMC Research Centre. 2016. Regulation Impact Assessment - Profit Distribution Model so called Estonian Model. Tbilisi: PMC Research Centre. https://idfi.ge/public/upload/Meri/Tako\%20Iakobidze/november_8_ppd_workshop_idfi_pmcg_p resentation.pdf. [Last seen 11.04.2021];

21. PwC. Doing Business and Investing in Georgia. Tbilisi: PwC. 2019. https://www.pwc.com/ge/en/assets/pdf/Doingbusiness_2019_Final.pdf. [Last seen 12.04.2021];

22. PwC, and World Bank. 2020. Paying Taxes Index. Brussels: World Bank Group;

23. PwC, and World Bank. 2016. Paying Taxes Index. Brussels: World Bank Group;

24. Vahter, Priit, Jaanika Meriküll, and Jaan Masso. 2011. "Gross profit taxation versus distributed profit taxation and firm performance: effects of Estonia's corporate income tax reform." Working Papers of Eesti Pank. No. 2/2011 3-48. 